\title{
REVIVAL AND UNITY OF REFORMED \\ CHURCHES: HOW TO DEAL WITH THIS \\ CHALLENGE? ALLAN BOESAK ON REFORMED CHURCHES AND THEOLOGY
}

\author{
Jerry Pillay \\ University of Pretoria \\ jerry.pillay@up.ac.za
}

\section{ABSTRACT}

This article reflects on the need for revival and unity in Reformed churches. It explores issues which prevent this from happening and offers suggestions as to how some of these challenges can be addressed. In attempting to do the latter it draws from the work of the World Communion of Reformed Churches. The article also especially recognises the work and contributions of Dr Allan Boesak as a Reformed theologian and scholar.

Keywords: Reformed churches; revival; unity; justice; mission; Reformed theology; Reformed spirituality; Allan Boesak

\section{INTRODUCTION}

In this article ${ }^{1}$ I shall briefly reflect on the meaning and relationship of revival and unity to one another. I shall stress the need for Reformed churches to seek revival and unity, explore some of the issues which prevent this from happening, and suggest ways in which Reformed churches can address these challenges by making specific reference to the work of the World Communion of Reformed Churches. In addition, this article is a special tribute to the Rev. Prof. Allan Aubrey Boesak, who once served as the President of the World Alliance of Reformed Churches in the 1980s. His devotion and commitment to Reformed theology, beliefs and practices, no doubt shine through in his sermons,

1 This paper was originally presented at a conference at the Chongshin University in Seoul, South Korea.

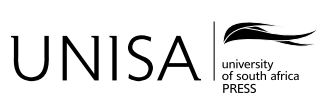


academic contributions and in his role as prophet, priest, pastor and theologian. The author attempts to highlight some of these in this article.

\section{REFLECTIONS ON REVIVAL AND UNITY}

In Acts chapter 2, we find the church in a state of revival and unity. The descriptive characteristics here for such a state are found in the fact that church members were: 1 ) united in prayer that brought them to one accord to one place; 2) filled with the Holy Spirit which signifies that it is God who brings revival; 3) devoted to the apostles' teaching, fellowship and the breaking of bread; 4) filled with awe and experienced many miraculous signs; 5) inspired to sell their possessions and goods and give to those who had need and; 6)praising God in their homes and enjoying the favour of all the people.

In this passage we see that revival and unity go together. Revival brings the people of God together in unity, and unity prompts revival and change. There is a tendency to separate the order of these two concepts: revival and unity. There are some who say that you have to have revival in order to have unity and there are others who say that you must have unity in order to experience revival. For example, Billy Graham illustrates the former in the following words: "The greatest need among Christians and churches today is for genuine spiritual revival. Wherever God has touched His people in special times of revival, lives have been changed, and Christians have experienced new power to do God's work (together)" (Johnson 2003, 346). Joy Dawson $(2005,77)$ expresses the latter in the following statement: "If the Lord were to pour out revival upon the body in the condition that we are in now, our current lack of unity would hinder us from being an adequate 'vessel' to hold and maintain the revival that He would pour out... I have changed my priority to pray for unity first, then revival. Unity in the body is a direct answer to Jesus' prayer in John 17, and a unified body provides a proper 'vessel' into which revival can be poured out."

It is true that the last prayer Jesus offered before going to the cross is for the unity of believers so that the world may believe. Judging by this it is clear that Jesus was concerned about the unity and witness of all believers. Jesus also realised that to be effective in God's mission in the world, believers would need to first receive the gift of the Holy Spirit. He thus cautioned the disciples to "wait for power from on high" (Acts 1:4) before they could go out to proclaim the good news. The point I wish to make here is that we need not spend too much time debating this issue. What matters most is that if Christians are to be effective witnesses in the world to Jesus Christ, then what they need are both revival through God's Spirit and Christian unity. Something that Allan Boesak painstakingly advocated in his prophetic witness and ministry (Dibeela, LenkaBula and Vellem 2014, 154). For him the unity of the church would lend credibility to its message in the world; it was only expected then that Christians should work for unity and justice.

The history of the Christian church all through the ages has shown the need for both revival and unity and though at different times certain aspects where emphasised, derived 
out of a particular context, the tendency has always been to see them together rather than apart. The church has needed at times to be revived because it lost its focus, purpose and excitement of witness. In this sense, revival refers to a spiritual reawakening from a state of dormancy or stagnation in the life of believers. It encompasses the resurfacing of a love for God, an appreciation of God's holiness, a passion for His Word and His Church, a convicting awareness of personal and corporate sin, a spirit of humility, and a desire for repentance and growth in righteousness. It generally involves the connotation of a fresh start with a clean slate, marking a new beginning of a life lived in obedience to God. Revival breaks the charm and power to live in the world but not of the world. In the following section I shall refer more to the aspect of Christian unity.

\section{CHALLENGES OF REVIVAL AND UNITY AMONG REFORMED CHURCHES}

The concept of revival and unity is not strange to Reformed churches. In fact, at the heart of the Reformation was the intent to reform, revive and renew the church. Basic for the understanding of ecumenism is that the Reformers did not intend to found a new church but sought reform of the whole church. In their minds the church was not standing up to the realities of its time in confronting financial corruption, sexual immorality and political power. Reformers such as Luther, Calvin, Zwingli and others called for the "reawakening" of the Church to address these issues (McGrath, 2012). In so doing they did not hesitate to point out the inadequacies and corruption of the church which impacted on its life, work, witness and theology. These, for example, are reflected in Luther's 95 Theses and Calvin's The Necessity of Reforming the Church (1543). This renewal was to impact on the structure, polity, theology, mission, worship and witness of the church.

It is sad that even in our day and age the Christian church is faced with similar challenges as we deal with corruption, political turmoil, sexual immorality, secularisation, spiritual apathy, religious factions, violence, abuse against children and women, and so forth. In most of these situations the church itself is not exempt from these challenges but, in fact, is sometimes responsible for or silent in the midst of these occurrences. It seems that what we need at this time is a revival of Reformed churches, which brings transformation within the church and in our world at large. We need to ask whether our structures and theological emphases are relevant for people in the world today. It must be recognised that many of our younger generation of Reformed people are not interested in the Reformed tradition, its confessions and its polity as such, but rather in a church which is effectively and imaginatively addressing the challenges of mission and outreach in our time.

While the Reformed tradition seems to grow in some parts of the world, it is true to say that in other parts it is declining and diminishing in significance and impact. We are mostly surrounded by churches that are aged, financially struggling, and irrelevant - and have already lost or are fast losing their place in impacting the community in which they 
are found. Whereas at one time Reformed churches were quite seriously involved in community transformation, economics and politics - and accused of the social gospel today we seem to retreat from society largely because of financial challenges and a lack of vision and focus to make a difference in the world.

Allan Boesak, no doubt, was a great proponent of this view of being involved in the transformation of society. For him, it was clear that Jesus Christ is Lord of all areas of life and this conviction undergirded his theological labour and his personal piety (Koopman in Dibeela et al. 2014, 36). For Allan Boesak, Jesus and politics did not represent a strange combination but a necessary one - if we are to truly live out the gospel and declare the Lordship of Jesus Christ. It was this firm belief that enabled him to put his own life at risk by opposing apartheid, and struggling against injustice and dehumanisation. His book Comfort and Protest... (1987) recounts and reflects his prophetic calling and ministry in these areas. Sadly, Reformed churches are being overtaken by other charismatic and Pentecostal churches, which once advocated a distancing from the engagement of the "this-world" focus and have now become the champions of what Reformed Christians have been saying all along. They are able to succeed in this, no doubt, because of their financial resources and growing membership. The tragedy is that many Reformed churches have become stuck in a maintenance mode rather than becoming a missional church. Perhaps added to this, is the ongoing fragmentation that Reformed churches continue to suffer today.

Reformed churches easily succumb to divisions. The history of the Reformed churches since the Reformation is a history of multiple divisions, and unfortunately the trend continues. Reformed churches have a tendency to split. In almost all countries in the world there is more than one Reformed church. Whilst in some places this may be the result of church planting by different missionary efforts, these are usually brought about by divergences over doctrinal or ethical issues or over aspects of church government or political options. In recent times the issues of the ordination of women and human sexuality has led to further divisions and strife. In such a context we need to hear afresh the need for Reformed churches to be driven by the agenda of unity and tolerance. Whilst diversity may be one of the strengths which keep the Reformed family together, it is becoming increasing apparent that it may also be its weakness.

John Calvin considered unity to be part of the nature of the church. His fourth book of the Institutes is a vivid expression of this conviction: On the True Church with whom we are to cultivate Unity because She is the Mother of all faithful (Institutes Book 4 Chapter1). He made repeated efforts to avoid the final rupture within the Church of Rome. In particular, he worked untiringly for the unity of the various Reformation churches. In this respect, his assumption was that as long as agreement on the essentials of faith was assured, diversity among the local churches was admissible. The one church consists of several Christian communions that are one in the essentials of the faith and recognise one another on this basis. Reformed theologians persisted in hoping that one day the divided churches would gather in a universal council and confess together the fundamental truths of the gospel. 
In the course of the centuries, Reformed churches were at the origin of many initiatives toward unity - both internal and intra-confessional. The hardening of the Reformed tradition into Reformed orthodoxy in the seventeenth and eighteenth centuries, and resulting splits, provoked counter-movements. Both in Pietism and the revival movements, the quest for unity was alive. In spite of numerous challenges Reformed theologians played an outstanding role in the beginning and shaping of the modern ecumenical movement (see McGrath 2012). The focus on Christian unity is on the agenda of many ecumenical organisations. One of the strongest proponents of this is the World Communion of Reformed Churches, established in 2010 with the coming together of the World Alliance of Reformed Churches (WARC) and the Reformed Ecumenical Council (REC).

In spite of these great efforts, internal division remains a characteristic of the Reformed family. While in some countries reunion of divided Reformed churches was successfully achieved (e.g. United States, Holland), the movement of dividing continues in other countries (e.g. Korea and parts of Africa).

\section{HOW CAN REFORMED CHURCHES SEEK REVIVAL AND UNITY?}

In the midst of these given realities we ask: How can Reformed churches seek revival and unity? We recognise the need for these, but what can be done to appropriate these ideals? In attempting to answer this question, I shall refer to the insightful work of the World Communion of Reformed Churches (WCRC) and its attempts to address the same, as well as the work of the World Alliance of reformed Churches (WARC). One of the clear objectives of the WCRC is to promote renewal and unity. In the Papers for the Uniting General Council of 2010 it stipulated how it would propose to achieve this through its seven core callings:

- To covenant for justice in the economy and the earth.

- To search for spiritual renewal and renewal of Reformed worship.

- To foster communion within the Reformed family and the unity of the church ecumenical.

- To interpret and re-interpret the Reformed tradition and theology for contemporary witness.

- To foster mission in unity, mission renewal and mission empowerment.

- To promote inclusivity and partnership in church and society.

- To enable Reformed churches to witness for justice and peace (WARC Papers for the Uniting General Council 2010).

In 2011 the Executive Committee of the WCRC took these callings and provided a further refined and renewed strategic direction in what is described as the five key 
directives (see WCRC Strategic Plan Document 2011, 4). The WCRC aims to revive, renew reform and work for unity among Reformed churches through these directives. I shall use these directives as a basis to suggest what can be done to work for revival and unity among Reformed churches.

\section{MISSION RENEWAL}

It is my personal belief that revival and unity of Reformed churches will come about more solidly and effectively by focusing on mission. The purpose of the church is to proclaim the good news of salvation and life in Jesus Christ. It does so in both word and deeds. In this we embrace the holistic understanding of mission which includes: (a) propagation of the faith; (b) expansion of the reign of God; (c) conversion of the heathen; and (d) the founding of new churches (Bosch 1999, 373).

The church as a community does not exist for itself. It has received a commission; it is sent into the world to proclaim and praise God. It is sent to be a sign, instrument and foretaste of the realisation of God's purpose in Christ for the whole humanity and creation. The mission of the church (and the churches) is founded on the sending out of disciples by Christ at the conclusion of his ministry and the empowerment of the Christian community for mission at Pentecost by the gift of the Holy Spirit.

The church and churches proclaim in the name of the crucified and risen Lord, God's saving grace and love for the whole world. In the midst of sin, brokenness, pain and suffering, it proclaims to the world in word and deed that God's salvation, hope and reconciliation have come into our midst in the life, death and resurrection of Jesus. It does so in the presence and power of the Holy Spirit. In his very powerful book, Dare we Speak of Hope?... (2014), Boesak speaks about the cutting-edge of mission and establishes that "Hope holds us captive, we cannot give her up, let go of her hand, lest we become utterly lost. Yet we know that where she is to be found is not in the places of comfort and safety. Christians have to look elsewhere (not to politicians) if we are to find a hope that is durable, life-affirming, and life-giving. If we are to challenge and change the world, [we must] keep looking to Jesus the pioneer and perfecter of our faith" $(2014,176)$. For Boesak the mission of the church, in the context of South Africa, must mean participation in reconciliation, justice and the building of the nation (Boesak 2005, 171). Mission must mean something more than merely "saving souls"; it must also transform the environment in which people live. The church thus becomes an agent of hope in a suffering and dark world.

If we want to see the revival of Reformed churches we need to put more focus and energy into the development of missional congregations. Mission happens essentially through local congregations and not in the bureaucratic structures of the denomination. We need to equip and empower local churches for mission in their given communities and beyond, something that Boesak firmly believed and worked for, and that can be seen in his many sermons. People join churches that are alive and making a difference 
in their communities - not ones that are insular and disconnected from the world. The key interest of young people today is not so much about faith-tradition, but about faithencounter. They are not so much interested in the tradition of their parents' church as they are in a church that is "doing" God's mission. They are keen to know about Jesus and what he means for the world today. This is the cutting-edge of mission: Who is Jesus for me today? If Reformed churches are to experience revival and unity, it is abundantly clear that it has to ask a new set of questions which relate to God and what is happening in the world. Its focus must not be exclusively internal, but consciously and intentionally external as it focuses on the world. Whilst Allan Boesak unashamedly prides himself on being Reformed, yet he is more interested in what this faith-tradition has to say to relevantly address the sufferings and evils in the world. His book Black and Reformed... (1984) is a commendable attempt to integrate and interrogate his Reformed beliefs from the perspective of the black church and suffering in South Africa. He commits to come to a truer understanding of the Reformed tradition and to accept the challenge to articulate [his] faith in terms that are authentic and relevant (Boesak 1984, $\mathrm{xv})$.

The first word of mission is God and not church. As we are drawn into our common understanding that the church is here to serve God's mission, we will realise the significance and necessity for unity. A mission focus will also call for a revival of the church's vision, purpose and structure. We need to ask whether Reformed churches are structured to meet the challenges in the world or are we going on with business as usual when the world around us is fast-changing?

Reformed churches often tend to split over issues that deviate from the actual mission and purpose of the church. The majority of people sitting in the pews often do not have a clue about what is happening; in fact they are not even interested. Instead, what they are looking for, praying for and hoping for, is the church witnessing to Christ in the world in the presence and demonstration of the Spirit's power - clearly what Boesak exemplified in his calling and ministry.

\section{COMMUNION AND CHURCH RENEWAL}

If Reformed churches are to experience revival and unity, then what is needed is a biblical and fresh understanding of what it means to be a communion and community of Christians working together in the name of the Triune God. Christian unity is something that we have to untiringly work for as Christians. Allan Boesak gave much of his energy, effort and time to work for such unity among the Dutch Reformed Church family in South Africa, which was fragmented by the institutionalisation of apartheid. He had been at the forefront of the reunification dialogue and process of these four churches and actively championed the endeavour of church unity by visiting churches and sharing information about the Belhar Confession and its stand for church unity, restorative justice and reconciliation. Unfortunately, this process still continues with this quest for church unity and Boesak is no longer directly involved in it. However, we have every 
reason to believe that his prayer and hope for Christian unity remains as strong as ever. The concept of Christian unity can be exemplified in the following comments:

- We are drawn together by the same Lord Jesus Christ who makes us one through his Spirit. Therefore, we are called to "make every effort to keep the unity of the Spirit in the bond of peace" (Eph. 4:3). This should find expression in all dimensions of Christian life: in witness, service, worship, and in sharing of spiritual life and economic and financial support.

- Communion (Koinonia) is not an association formed by the common interest of individuals of equal social standing. It is a gift of God that implies the commission to Christians to shape their lives as Koinonia, and acknowledge this gift in their Koinonia with one another (John 17). It is this use of Koinonia as a relational concept, integrating the different dimensions of the life of the Christian community that accounts for its significance for contemporary ecclesiological reflection and ecclesial practice.

- We are one in Christ. This unity, however, does not mean uniformity. We are not called to suppress our unique and diverse particularity. In Christ our diversity is embraced and transformed into a mutually supportive communion. This communion requires more than mutual tolerance; it calls us to a mutual recognition, acknowledgement, and welcome. We are bound by the love of Christ which enables us to love the other.

- The reality of communion invites us to live out our unity with greater recognition and acceptance of diversity and realise our diversity with a greater will toward unity. However, diversity is not fragmented unity, and unity cannot be cemented diversity. The love of God in Christ Jesus calls us to be more.

- It is quite disturbing to learn that in some parts of the world Reformed churches are literally at war with each other to the extent of violence and bloodbaths, using military might, power and government influence to stake their claim and authority. It is also alarming to see how many churches are fighting their battles in the courts of law and bringing injury and insult to their Christian witness in the world.

- Without attempting to pontificate on these matters, this article humbly contends the following: Our unity must be reconceived as the mutual interaction of the many differing views on the subject to find mutual flourishing and blessing to others. Mission is based upon a theology of generosity and hospitality arising from our understanding of the truth which is revealed in Christ. Yet we must be willing to risk that understanding in conversation with others. Just as mission involves giving and receiving, gathering and multiplying, so it also involves challenging and being challenged. In being challenged, we need something more than arguments and counter-arguments. We need to find each other in the love, grace, peace and unity of Jesus Christ. 
- Recognising the church as created by God, we need to learn to affirm the gift of communion with one another and "maintain the bond of love", despite diversities and conflicts, imperfections and frustrations that arise from failures in the face of difficulties. Reformed churches need to ask what justifies their separate existence and to consider opportunities for developing new bonds of communion. Reformed churches accept the liberty of opinion and accommodate a variety of views. In this light, are we not prepared to agree to disagree in the desire to preserve something of greater importance: the unity of the church and its witness to the world?

Although the points mentioned above are not directly attributed to Allan Boesak, they resonate well with his own views as expressed in his writings. It is in keeping with his quest for unity, justice, peace and reconciliation.

\section{JUSTICE AND CHURCH RENEWAL}

If Reformed churches want to experience revival and unity then they have to give greater consideration to the quest for their relevance in the world today. One of the key focal points for relevance is related to the issues of justice, struggles and sufferings in the world and how the Christian church is attempting to address these. People in the pews want answers to their questions and they are not merely content with avoidance or spiritualisation of these issues. They want to engage and understand them as they wrestle with their beliefs and faith. The social realities of our world have created a spiritual crisis that causes many youths to lose hope, and avoid relationships with God and with each other. In this sense, the matter of justice becomes crucial if we want to experience revival and unity.

For Allan Boesak the issue of justice is crucial; it is part and parcel of the Christian gospel (Dibeela et al. 2014, 218). In fact, it is the declaration of the Lordship of Jesus Christ. Whenever Christians speak out and act against injustice, inequality and the dehumanisation of a human being, they serve as the ambassadors and servants of Christ. Boesak singles out the Belhar Confession in this respect, where it states "in a world filled with injustice and enmity, God in a special way is the God of the destitute, the poor and the wronged...that the church as God's possession is called to stand where God stands, namely against injustice and with the wronged" (see Boesak 2008, 143-172). Boesak points out that this Confession helps us to, first, stand up (and be counted) for the poor and the destitute, and second, to stand where God stands. Not just in front of, in protection, but alongside, in solidarity of struggle. Not in mere sympathy but in identification with. The church must do that not because it is obsessed with the poor, but as the possession of God, in Whom its grounds of being and its identity are found (Boesak 2005, 200).

In this sense, we need to explore what Reformed churches can contribute to alleviating suffering and to transforming our societies. God created this world and wants to preserve the world until it comes through its end to its future in a "new heaven and a new earth" (Rev. 21:1). It is God's will that human life be a life in communion, 
peace and justice. Boesak certainly understands this and he has constantly pleaded for this deep integration of unity, justice and peace.

Of course, this knowledge is not new to Reformed Christians. The founding history of the ACCRA Confession (2004) has spoken to this quite strongly and powerfully in its reference to economic justice, gender justice and eco-justice. This Confession speaks extensively about "covenanting for justice and the care of the environment and earth". It also offers a critique on the Empire and explores its damaging effects in the globalised world. Boesak has offered valuable theological reflection on Empire and establishes that the Christian church today is facing "a new Rome" (Boesak and Hansen 2009, 59-72). Consequently, he states that the church is called to resist all these new forms of idolatry for they have moral, political, economic and theological consequences. It is thus not surprising, as Dirkie Smith has shown (in Dibeela et al. 2014, 11-35), that in Boesak's publications and sermons the crucial importance of power as a theme in both his life and thought are quite evident. Boesak has unceasingly offered a solid critique on the concept of power from a justice perspective (Dibeela et al. 2014, 11-15).

It is encouraging to note that the ACCRA Confession has been offered as a gift to other ecumenical bodies, some of which have taken ownership of it and formulated their own theological statement and work on its declarations. Moreover, some of the things it has stated have come true, for example the economic recession we encountered in 2008 and 2013. The challenge now is to continue to live out this Confession in our daily lives and practices. Perhaps this challenge needs to begin with us as Reformed believers. Proclaiming truth to power and exercising our prophetic calling can sometimes embarrass ourselves because we often struggle to practise what we preach. . During a visit the author undertook to India, he had the opportunity to visit a Dalit village where the "untouchables" and poorest of the poor live. Upon enquiry from the church leaders about what they were doing to challenge the existent caste system and help the people in the village; they confessed that they were not doing much. On further prodding, it was disclosed that the church was benefiting from the system and therefore preferred to remain silent. It is sad that the church should allow itself to become susceptible to the temptations of power, but it is a reality in many parts of the world. Boesak and Desmond Tutu were the leading voices challenging the position of the church in South Africa in the days of apartheid. They were instrumental in forcing the church to take sides; not with the rich and powerful, but with the poor, oppressed and marginalised.

Within the WCRC, the impression is sometimes that we do not mind talking about church unity, but we get slightly irritated when we talk about justice. We need to understand that the God of justice and peace expects us to work towards these as well. We cannot have communion (unity) without justice or justice without the desire for communion (unity). Justice is a necessary part of building a communion. We cannot have true unity without addressing issues of injustice. This evidently has been and still is Boesak's valid belief and practice. 


\section{RENEWAL OF REFORMED THEOLOGY}

As we speak about revival and unity, we must recognise that everything we believe, say and do needs to be theologically and biblically based. There are many emerging trends practised among churches today that are biblically questionable and even untenable. Nevertheless, for some reason they tend to flourish. An example of this is the rise of churches that focus on the "prosperity gospel" and motivational speeches for sermons; yet they seem to draw hundreds and thousands of people. While Reformed Christians should not be driven by fads and trends, it is imperative that we ask fresh questions in terms of our theological emphases and priorities. Instead of seeking to be critical and judgmental of these developments, would it not be more appropriate to ask what we can learn from them and why are they growing at a rate that we do not usually see among Reformed churches, at least in Africa?

Central to the sixteenth century Protestant Reformation is allegiance to the authority of the Bible as God's word; continuing recognition of that authority is basic to our identity in Christ as guided by the Holy Spirit (2 Tim. 3, 16-17). In Reformed theology, we affirm our focus on the sovereignty of God, covenantal theology, the priesthood of all believers, sola scriptura, sola fide, sola gratia, and so forth. As Reformed churches we are also informed by creedal and confessional documents that summarise our understanding of Scripture. In some places we are still having conversations, debates and disagreements over certain confessions and declarations. These are valid and necessary and we should not undermine them in any way but we should also be mindful of what Christians are concerned about today. In 2013 the author chaired a conference where brilliant papers were presented on the Heidelberg Confession, and was deeply moved by what was said then and how relevant it is for us today. But that is precisely the problem; as Reformed theologians and pastors we are failing to adequately relate these awesome Confessions and teachings to our given realities and modern-day life situations. Therein remains the challenge! We need to submit our own traditions and ambitions to constant reformation by the Spirit as we live as followers of Jesus Christ in ever changing cultures (Ecclessia reformata semper reformanda - the Reformed church always has to be reforming.)

In such an evolving context we need fresh understandings of Reformed theology and new expressions of Reformed identity. We need to take all that we have in the pool of Reformed theology, tradition, practice and spirituality and embed it in a contextual theology which reflects on our current realities, if we are to encourage revival, growth and unity. This is precisely what Allan Boesak did in his academic contributions, preaching, church leadership and in his brief stint in politics (Boesak 2014, 67-89). Particularly outstanding is his theological contributions and his pioneering efforts to interpret Reformed theology in the South African and African context. Given the devastating misinterpretation of Reformed theology and tradition in the justification of apartheid, Boesak managed to recapture the true essence of what Reformed theology is all about. His books Farewell to Innocence... (1976) and Black and Reformed... (1984), 
among others, are incredible attempts to cast a new light on Reformed theology, while seriously engaging the black experience and context. This is further explored in his endeavour to connect the concept and quest for an African renaissance with Christian theology and faith, which he does so well in his book The Tenderness of Conscience... (2005). These are wonderful signs of hope and life that we must continue to encourage as we seek to "pour new wine into old wineskins". Indeed, Boesak has pioneered and set the ground and many others have since followed suit in the continuous attempt to keep reforming the Reformed faith and tradition. This, ultimately, is necessary for revival, renewal and (contextual) relevance.

\section{SPIRITUAL AND WORSHIP RENEWAL}

Getting back to the revival and unity we see in Acts chapter 2, we discover a community thriving in spirituality and worship. They are found praying, praising and worshipping God as they gave themselves to the study of Scripture, fellowship, breaking of bread and selling their possessions and giving to the needy. The signs and characteristics of revival and unity speak of the renewal of worship which makes it a powerful, daily and devoted experience. This is something that Reformed churches must take cognisance of, if they are to seek revival and unity.

Having listened to many sermons and addresses given by Allan Boesak, one of the things that constantly emerge is his profound depth of spirituality. Although he does not profess to be a biblical scholar, his regular use of Scripture in his presentations and writings exudes his sincere love for the Word of God. He understands that the worship of the Triune God is at the heart of everything in both life and death. Setri Nyomi, former General Secretary of WARC and the WCRC, captures this well: "Allan Boesak is a prophet who has understood that the issues of justice, peace and human rights must be linked with prayer that leads to mission and action. Boesak's passion for living out that call - in his writings, his actions against the evil of apartheid in South Africa and in his visionary leadership of the World Alliance of Reformed Churches in the 1980s - are all vivid testimonies to how effectively he has understood these linkages" (in Dibeela et al. 2014, 111).

Reformed churches have experienced and are experiencing conflicts, divisions and splits around the area of worship. What constitutes a proper liturgical style and basis for Reformed worship? There are some who have left the Reformed church because they believe that its style of worship is not what they prefer, and if they desire to effect change then they must leave the Reformed family. However, this is not true about the Reformed church because in reality we embrace a variety of ways and styles in worship and have the freedom to do so; yet in many local churches leaders are not prepared to think creatively about worship. In my own denomination I have come across leaders who are prepared to see their young children and youth go to other churches rather than change the way they prefer worship: loud music, instruments and free style of praise and singing and use of spiritual gifts are simply not welcome. In most parts in Africa, 
for example, Reformed Christians seem to suffer an identity crisis because deep in their hearts they prefer Reformed teachings but in the expressions of worship they are more at home with Pentecostals. They love singing, dancing and being moved by the presence and power of the Holy Spirit.

It is true that some of the Reformers, like Calvin, had much to say about worship and particularly music and singing in church. However, we need to realise that what was said in their time has to be relooked at in this new century. The fact of the matter is that most young people prefer more contemporary songs and music, visuals, lights, loudness, and so forth. It is imperative that we seek to find ways of integrating young people into the church; they are not just the church of tomorrow but, indeed, the church of today. It is okay to change our styles and approaches as long as we are able to maintain and teach in and through all of these mediums, the substance and essentials of our faith. There are many Reformed churches that are providing a balanced worship, which caters for the needs and preferences of the variety of its members.

Part and parcel to the Reformed heritage is the stressing of the spiritual disciplines of prayer, fasting and the study of the Word. These are the "power" bases for revival brought about by the Holy Spirit of God. For some reason these spiritual disciplines seem to be less emphasised in Reformed churches today. If we are to truly encounter revival and unity we need to return to these essential spiritual practices. It has been noticed that churches which encourage and exercise these spiritual disciplines are flourishing in numerical and spiritual growth. However, what is most essential to worship, as expressed by Boesak, is that worship in the sanctuary must be connected with the lived experiences on the streets. This can be captured in his own words: "I have preached, marched, demonstrated. Half my ministry has become a confrontation with the South African government and its forces, in pulpit and, because of that, in the streets" (Boesak 1987, 13). Spirituality pervades every aspect of life: social, political and economic. The real life encounters of people's struggles must inform and inspire our worship to express both faith and obedience to God. Worship must become a lifestyle that engages transformation and change as we address sin, oppression and dehumanisation in the world. As Boesak $(1987,14)$ would put it, our faith in Jesus Christ demands this.

\section{RENEWAL OF ECUMENICAL ENGAGEMENT}

It is often said that to be Reformed is to be ecumenical. This has, no doubt, been clearly visible in the history of Reformed churches worldwide. Reformed churches have strengthened ecumenical movements in their participation, desire and efforts for unity among churches. If Reformed churches want to experience revival and unity, it is necessary for them to continue to sustain ecumenical engagement and involvement.

Added to this is the knowledge that we cannot tackle all the problems in the world by ourselves. We need to link, connect and work with other churches and organisations in order to make a difference of substantial impact. As Reformed churches we need to work with other churches, Christians and organisations to address the realities in the 
world. We may also be required to work with organisations that are not necessarily Christian and with organisations and people of other faiths, or no faith, to address issues of poverty, religious factions, reconciliation and peace, education, health, and so forth. Boesak was particularly mindful of this and, no doubt, he used his ecumenical leadership of the WARC and other ecumenical contacts to bring pressure on the apartheid regime in South Africa (Boesak 1987). There is no doubt that such relationships put South Africa on the world map and eventually led to the dismantling of apartheid. Boesak also used these ecumenical connections to help in the reconstruction and development of the postapartheid South Africa (Boesak 1987).

In some parts of the world ecumenical interest is dwindling and ecumenical organisations are struggling to survive financially; this is symptomatic of the lack of interest and involvement by local churches and denominations. Ecumenical organisations must direct their vision and efforts into mobilising and equipping local congregations and member churches for mission in the world. Over the years it has become clear that true ecumenism is to be found in the pews and not among church leaders who are often bent on protecting their territorial and ecclesial turf related to doctrine, polity and practice. It is the ordinary Christians who are more inclined to work well with others to make a difference in the world. As indicated earlier, churches that are growing and experiencing revival and unity are churches that are taking a keen interest in transforming their communities and working with others to bring about change in people's lives and circumstances. Reformed churches need to reawaken to this call and realise the significance of engagement and participation. God calls us to be a community and to work in community to build community. We are not called to be lone rangers on a mission for God. As Boesak would say, we are called to be God's people working with others led by the presence and power of God's spirit to bring transformation, healing, reconciliation and peace in the world (Boesak 1995, 27). We do this best when we join with other churches and organisations.

\section{CONCLUSION}

We live in a day and age where many challenges and contradictions face the Christian church. In order to address these challenges, we are called as Christians to witness and work together as we proclaim the good news of salvation and life in Jesus Christ. In this context, we are also alarmed by how Reformed churches continue to experience splits, breakaways, divisions and conflicts instead of seeking unity in our witness and mission as we bear witness to the saving love and grace of God in Jesus Christ. It is no wonder then that in some parts of the world the Reformed church is diminishing in significance and declining in numbers. In other parts of the world though, they seem to grow in numbers yet they continue to divide and fragment, weakening their base and sending mixed messages to the people around them. How much more effective would they be if they maintained unity and worked together? Unity does not speak of uniformity but there is the possibility of reconciled diversity. It is true; as we look around us today in 
the world we need revival and unity of Reformed churches. This can come about by seeking renewal in mission, communion, justice, theology, spirituality and worship, and ecumenical engagement. In the final analysis, no matter what we seek to do we must know that true revival and unity comes from God who moves amongst us through the presence and power of his Holy Spirit as in the case of the early church in Acts chapter 2. It all begins with God; may revival and unity be the desire of Reformed churches today. Reformed churches need to continue in their quest to renew and transform the world as they work towards the ideals of unity, justice, peace and life in abundance for all people, especially the poor, oppressed and dehumanised ones. This article contends with absolute confidence that in responding to this, Boesak would say "Amen!"

\section{REFERENCES}

Boesak, Allan Aubrey. 1976. Farewell to Innocence: A Social-Ethical Study of Black Theology and Power. South Africa: Ravan.

Boesak, Allan Aubrey. 1984. Black and Reformed Apartheid, Liberation and the Calvinist Tradition. Johannesburg: Skotaville Publishers.

Boesak, Allan Aubrey. 1987. Comfort and Protest: Reflections on the Apocalypse of John of Patmos. Edinburgh: St Andrews Press.

Boesak, Allan Aubrey. 1995. "The Church and the RDP." In The Reconstruction and Development Programme: The role of the Church, Civil Society and NGOs, edited by Renier Koegelenberg. Cape Town: EFSA.

Boesak, Allan Aubrey. 2005. The Tenderness of Conscience: African Renaissance and the Spirituality of Politics. Stellenbosch: Sun Press.

Boesak Allan Aubrey. 2008. "To Stand Where God Stands.” Studia Historiae Ecclessiasticae, 34, no. 1, Pretoria: UNISA Press.

Boesak, Allan Aubrey. 2014. Dare we Speak of Hope? Searching for a Language of Life in Faith and Politics. Michigan: W. B. Eerdmans Publishing.

Boesak, A., and Hansen, L. 2009. Globalisation: The Politics of Empire, Justice and the Life of Faith. Stellenbosch: Sun Press.

Bosch, D. 1999. Transforming Mission: Paradigm Shifts in Theology of Mission. Maryknoll, New York: Orbis Books.

Dawson, J. 2005. The Fire of God: Discovering its many Life Changing Purposes. USA: Destiny Image Publishers.

Dibeela, P., Lenka-Bula, P., and Vellem, V. 2014. Prophet from the South: Essays in Honour of Allan Aubrey Boesak. Stellenbosch: SUN Press. 
Johnson, T. P. 2003. Examining Billy Graham's Theology of Evangelism. Oregon: Wipf and Stock Publishers.

McGrath, A. E. 2012. Reformation Thought an Introduction. UK: Wiley-Blackwell.

WARC, 2010. Papers for the Uniting General Council. Geneva: WARC Publication.

WCRC, 2011. WCRC Strategic Plan Document. Geneva: WCRC Publication. 